\title{
Ultra low dose 2D/3D digital Xray system
}

\author{
Jacques A de Guise*, Stefan Parent \\ From 7th International Conference on Conservative Management of Spinal Deformities \\ Montreal, Canada. 20-22 May 2010
}

EOS is an ultra low dose 2D/3D digital Xray system developed by Biospace Med and a team of France Quebec engineers and clinicians. EOS is based on the Nobel Prize for Physics winner Georges Charpak's detector technology that has been adapted for clinical Xray imaging. It allows for the simultaneous acquisition of two perpendicular digital images of patient in a weight-bearing standing position. Using a stereoradiographic reconstruction scheme based on a priori geometrical and statistical information about the 3D bones, dedicated software allows for the reconstruction and dynamic visualization of the $3 \mathrm{D}$ bone surface of the spine, the pelvis, the femur, the tibia, etc. Once the 3D models are obtained, it is then possible to obtain automatically over 100 true 3D angle and length measurements (cobb angles, vertebral rotations, wedging, kyphosis, lordosis, pelvic parameters, pangonogram data). Software also allows making any $3 \mathrm{D}$ desired measurements, using a set of simple interactive tools. A dosimetric study done in our laboratories has shown a 6 to 9 fold decrease in dose received by the patients compared to a normal full-length spinal exam. Furthermore, applications are being developed to evaluate the 3D deformity pre-operatively and post-operatively. A recent retrospective study identified several 3D parameters distinguishing patients with significant curve progression when compared to a group of patients with no progression of their initial scoliotic curve at maturity. These findings are currently evaluated in a prospective study.

Published: 10 September 2010

Submit your next manuscript to BioMed Central and take full advantage of:

- Convenient online submission

- Thorough peer review

- No space constraints or color figure charges

- Immediate publication on acceptance

- Inclusion in PubMed, CAS, Scopus and Google Scholar

- Research which is freely available for redistribution

Submit your manuscript at www.biomedcentral.com/submit
C Biomed Central 